\title{
CHEMICAL SYNTHESIS AND DENSIFICATION BEHAVIOR OF Ag/ZnO METAL-MATRIX COMPOSITES
}

\author{
OBNAŠANJE Ag/ZnO KOMPOZITA S KOVINSKO OSNOVO PRI \\ KEMIJSKI SINTEZI IN ZGOŠČEVANJU
}

\author{
Mohammad Ardestani \\ Islamic Azad University, Science and Research Branch, Department of Materials Engineering, Tehran, Iran \\ ardestani80@gmail.com \\ Prejem rokopisa - received: 2014-09-24; sprejem za objavo - accepted for publication: 2015-04-07
}

doi:10.17222/mit.2014.243

\begin{abstract}
In this research, the chemical synthesis and densification behavior of $\mathrm{Ag} / \mathrm{ZnO}$ metal-matrix composites were investigated. The initial precipitates were obtained by adding ammonium carbonate solution to silver and zinc nitrate solutions. The precipitates consisted of silver and zinc carbonates. The thermal behavior of the precipitates was studied using thermogravimetric analysis (TGA) and differential scanning calorimetry (DSC). The TGA curve showed three distinguishable mass-loss stages, related to the evaporation of physically adsorbed water and also the decomposition of silver and zinc carbonates into silver and zinc oxides, respectively. The mass-loss stages were associated with three endothermic reactions. According to the thermal-analysis results, the precipitates were calcined at $600{ }^{\circ} \mathrm{C}$. The compressibility behavior of the synthesized $\mathrm{Ag} / \mathrm{ZnO}$ powders was evaluated using the Heckel, Panelli and Ge models. The compaction data of the powders was best fitted to the Heckel equation. The synthesized powders were sintered at $930^{\circ} \mathrm{C}$. The results showed that by increasing the cold-compaction magnitude prior to sintering, the sinterability of the powders was enhanced. The microstructural evaluation of the synthesized composites carried out with a scanning electron microscope (SEM) confirmed a fine and homogenous dispersion of ZnO within the silver matrix. Keywords: Ag/ZnO composites, densification, thermal analysis, sintering

V raziskavi je bilo preiskovano obnašanje Ag/ZnO kompozita na kovinski osnovi pri kemijski sintezi in zgoščevanju. Začetni izločki so bili dobljeni z dodatkom raztopine srebrovega in cinkovega karbonata v raztopino amonijevega nitrata. Izločki so bili sestavljeni iz srebrovega in cinkovega karbonata. Toplotno obnašanje izločkov je bilo posneto s termogravimetrično analizo (TGA) in z diferenčno vrstično kalorimetrijo (DSC). TGA krivulja je pokazala stopnje občutne izgube mase, ki so bile povezane $\mathrm{z}$ uplinjanjem fizično adsorbirane vode in tudi $\mathrm{z}$ razgradnjo srebrovega in cinkovega karbonata $\mathrm{v}$ srebro in $\mathrm{v}$ cinkov oksid. Stopnje izgube mase so bile povezane s tremi endotermnimi reakcijami. Na podlagi rezultatov termoanalize so bili izločki kalcinirani pri $600{ }^{\circ} \mathrm{C}$. Stisljivost sintetiziranega Ag/ZnO prahu je bila določena z uporabo Heckel, Panelli in Ge modelov. Podatki za kompaktiranje prahov so se najbolje ujemali s Heckel enačbo. Sintetizirani prahovi so bili sintrani pri $930{ }^{\circ} \mathrm{C}$. Rezultati so pokazali, da povečevanje obsega zgoščevanja pred sintranjem pospešuje sposobnost prahu za sintranje. Ocena mikrostrukture sintetiziranega kompozita $\mathrm{z}$ vrstično elektronsko mikroskopijo (SEM) je potrdila drobno in homogeno razporeditev $\mathrm{ZnO}$ v osnovi iz srebra.

Ključne besede: Ag/ZnO kompoziti, zgoščevanje, termična analiza, sintranje
\end{abstract}

\section{INTRODUCTION}

Silver-matrix particle-reinforced composites are used in several types of electrical contacts with different applications such as starting switches, oil- and air-circuit breakers, relays and thermostat controls. The properties of the contact depend on the characteristics and volume fraction of the reinforcement(s). Various non-refractory and refractory metals and hard materials like iron, tungsten, molybdenum, tungsten carbide and zinc oxide are used as the reinforcement for this group of metal-matrix composites. Silver-matrix composites are made with the melt-cast method or manufactured with powder-metallurgy (P/M) processes. ${ }^{1}$ The conventional P/M method, applied as the manufacturing process includes cold compaction and sintering of silver and reinforcing constituent powder blends. ${ }^{1,2}$

The magnitude of the cold-compaction pressure and sintering temperature significantly affects the final sintering density and other physical properties of the powder compacts. Recently, it has been shown that a fine and homogenous dispersion of the reinforcement within the matrix phase leads to the desired electrical advantages like the arc stability and also a reduction of the arc-erosion rate of a contact. ${ }^{3}$ Different methods like mechanical milling ${ }^{4,5}$, mechanochemical ${ }^{6}$ and chemical precipitation $^{7}$ were applied to synthesize the particle-reinforced silver-matrix composites with a fine dispersion of the reinforcing phase.

In this research, a synthesis of $\mathrm{Ag} / \mathrm{ZnO}$ powders via the chemical-precipitation process was investigated. Also, the effect of the cold-compaction pressure magnitude prior to the sintering on the solid-state sinterability of the synthesized powders was studied. Furthermore, the compressibility behavior of the synthesized powders was evaluated using the Heckel, Panelli-Ambrosio and Ge models: $: 8$

$\ln \left(\frac{1}{1-D}\right)=K P+B_{1} \quad($ Heckel equation $)$ 
$\ln \left(\frac{1}{1-D}\right)=\sqrt{K P}+B_{2}$ (Panelli-Ambrosio equation)

$\lg \left[\ln \left(\frac{1}{1-D}\right)\right]=K \ln P+B_{3}($ Ge equation $)$

where $D$ is the relative density, $P$ is the cold pressure and $B_{1}, B_{2}$ and $B_{3}$ are the constants.

\section{EXPERIMENTAL WORK}

Silver and zinc nitrate were used as the precursors. In order to synthesize the $8 \%$ of mass fractions of $\mathrm{Ag}, \mathrm{ZnO}$ powders, silver and zinc nitrate solutions were made in distilled water separately. A 0.5 molar solution of ammonium carbonate was added to the prepared solutions drop by drop. Subsequently, the prepared solutions containing the precipitates were mixed and the prepared mixture was stirred vigorously for $3 \mathrm{~h}$ at $50{ }^{\circ} \mathrm{C}$. In order to determine the appropriate calcination temperature of the obtained precipitates, the thermal behavior of the precipitates was investigated using simultaneous thermal analysis (STA) up to $800{ }^{\circ} \mathrm{C}$ with a heating rate of 10 ${ }^{\circ} \mathrm{C} / \mathrm{min}$ in air atmosphere. On the basis of the STA result, the precipitates were calcined at $600{ }^{\circ} \mathrm{C}$ for $2 \mathrm{~h}$. The calcined powders were characterized with the X-ray diffraction (XRD) technique. The calcined powders were cold compacted with $(100,200$ and 300) $\mathrm{MPa}$ in a 10 $\mathrm{mm}$ diameter cylindrical die and sintered at $930{ }^{\circ} \mathrm{C}$ for 2 $\mathrm{h}$ in air atmosphere. The microstructures of the powders and the sintered composites were evaluated with scanning electron microscopy (SEM).

\section{RESULTS AND DISCUSSION}

Figure 1 shows the microstructure of the initial precipitates. According to this figure, the particles have cylindrical and polygonal shapes. One of the advantages of the applied precipitation process was the use of chemical precursors that did not contain sodium. This agent was used due to the agglomeration of the synthe-

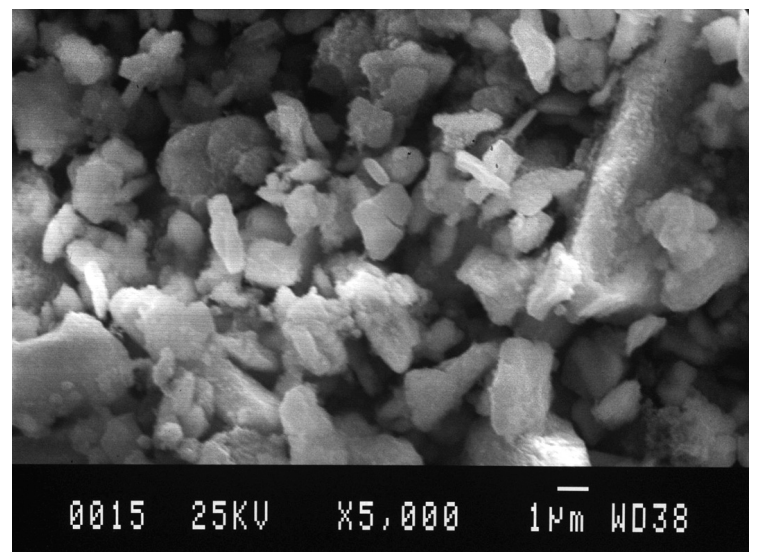

Figure 1: SEM image of the initial precipitates Slika 1: SEM-posnetek začetnih izločkov

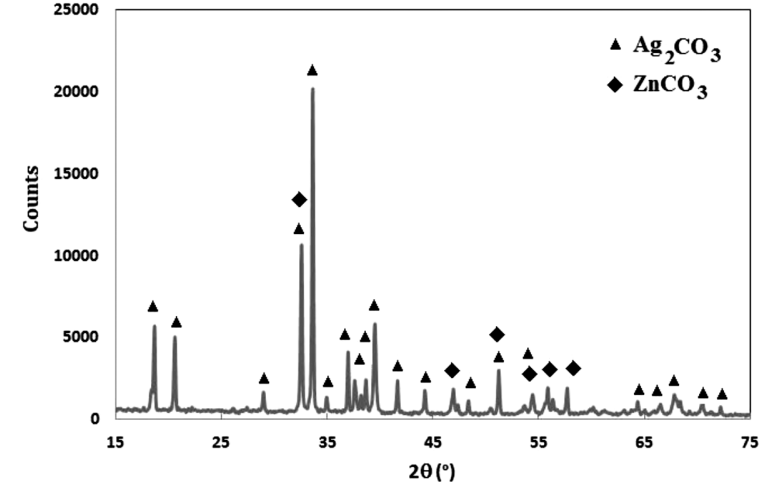

Figure 2: XRD pattern of the initial precipitates Slika 2: Rentgenogram začetnih izločkov

sized precipitates. However, in order to decrease the agglomeration degree of the particles, the synthesized compounds should be washed for several times, which is a time consuming process. The XRD pattern of the precipitates is shown in Figure 2. According to the XRD pattern, the precipitates consisted of silver and zinc carbonates.

The TGA, DTG and DSC curves of the initial precipitates are shown in Figures $\mathbf{3 a}$ and $\mathbf{3 b}$. According to the TG and DTG curves, the mass loss of the precipitates occurred up to $600{ }^{\circ} \mathrm{C}$ and above this temperature no detectable mass change is seen in the TGA curve. This
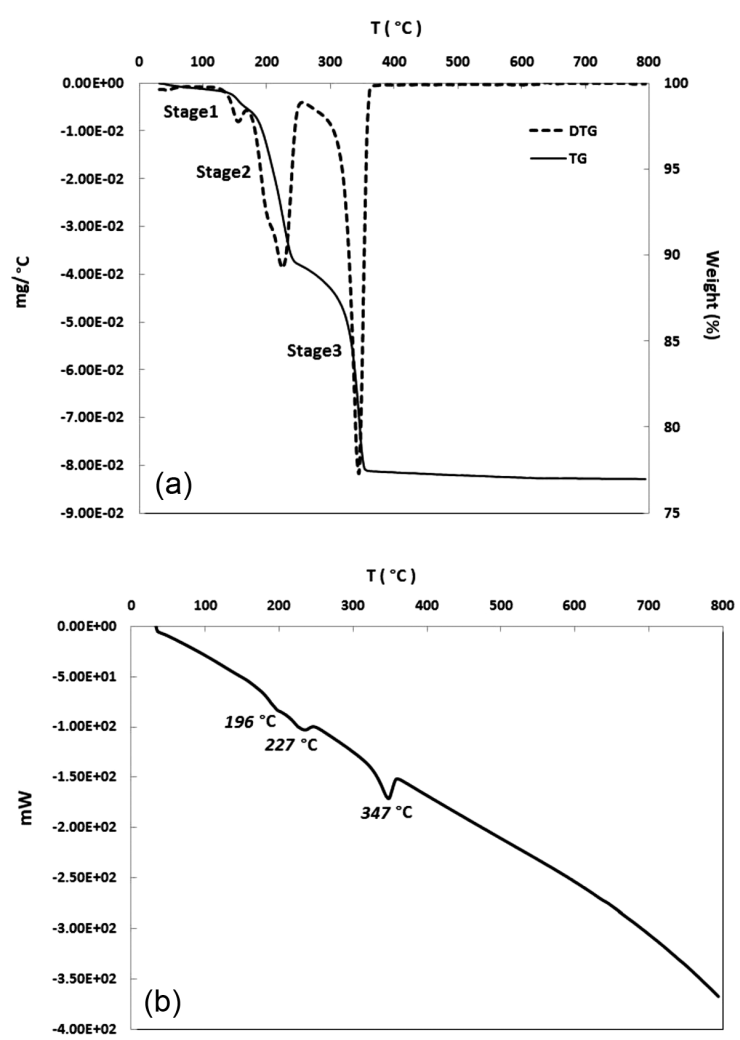

Figure 3: a) TGA and DTG curves of the initial precipitates, b) DSC curve of the initial precipitates

Slika 3: a) TGA- in DTG-krivulji začetnih izločkov, b) DSC-krivulja začetnih izločkov 
observation shows that the volatile constituents, such as carbon dioxide, evaporated completely due to the heating of the initial precipitates at $600{ }^{\circ} \mathrm{C}$. Also, according to the DSC curve, the decomposition of the precipitates was due to three endothermic reactions at $(197,226$ and 346) ${ }^{\circ} \mathrm{C}$. So, the appropriate calcination temperature of the initial precipitates was $600{ }^{\circ} \mathrm{C}$.

The XRD pattern of the calcined precipitates is shown in Figure 4. This pattern confirms the formation of $\mathrm{Ag}$ and $\mathrm{ZnO}$ during the calcination that was due to the decomposition of silver and zinc carbonates, respectively. The SEM image of the calcined powders is shown in Figure 5. As it is observed, the particles were agglomerated due to calcination at $600{ }^{\circ} \mathrm{C}$. Furthermore, it seems that the heat treatment of the initial precipitates and also the evaporation of the volatile compounds led to considerable microstructural changes of the precipitates during the calcination.

The result of the XRD analysis is in good agreement with the theoretical weight-loss measurements of the precipitates during the calcination that can be calculated using the thermogravimetric curve. According to the TGA curve, the total weight loss during the calcination is $24 \%$. The theoretical weight loss of the sample can be calculated considering the XRD analysis of the initial and calcined precipitates as shown below:

$$
\begin{gathered}
\mathrm{Ag}_{2} \mathrm{CO}_{3}, \mathrm{ZnCO}_{3} \rightarrow \mathrm{Ag}, \mathrm{ZnO} \\
\% \text { total weight loss }=\frac{2 m_{\mathrm{Ag}}+m_{\mathrm{ZnO}}}{m_{\mathrm{Ag}_{2} \mathrm{CO}_{3}}+m_{\mathrm{ZnCO}_{3}}} \approx 74 \%
\end{gathered}
$$

$$
100-74=26 \% \text { (theoretical weight loss) }
$$

where $\mathbf{m}$ is the molar weight of the constituent.

The difference between the theoretical calculations and experimental data ( $2 \%$ ) may be due to the evaporation of the physically adsorbed water during the first weight-loss stage of the sample. According to the TGA curve, the weight loss of the precipitates during the first stage is $1.5 \%$, which is too close to the difference value. The second stage of the weight loss in the TGA curve corresponds to the decomposition of zinc carbonate to

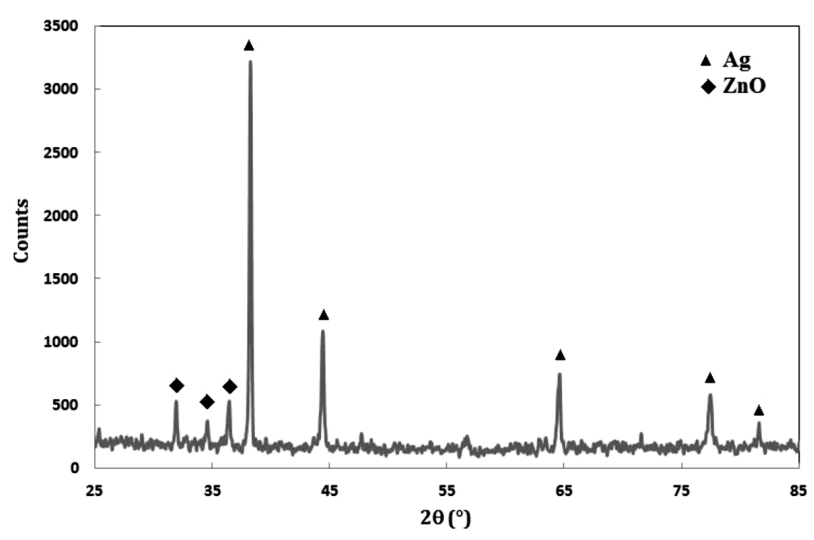

Figure 4: XRD pattern of the calcined precipitates Slika 4: Rentgenogram kalciniranih izločkov

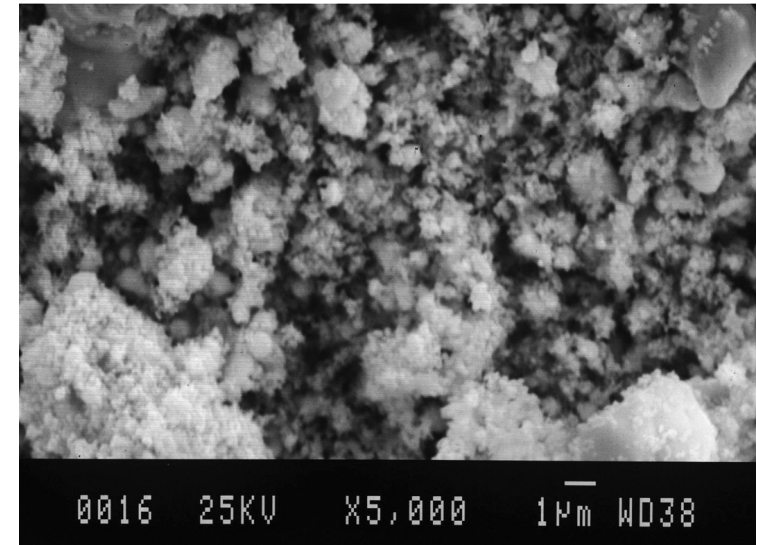

Figure 5: SEM image of the calcined powder. The powder particles are agglomerated.

Slika 5: SEM-posnetek kalciniranega prahu. Delci prahu so aglomerirani.

zinc oxide. The corresponding weight loss of the sample during the second stage is about $10.5 \%$, which is in good agreement with the theoretical calculation:

$$
\mathrm{Ag}_{2} \mathrm{CO}_{3}, \mathrm{ZnCO}_{3} \rightarrow \mathrm{Ag}_{2} \mathrm{CO}_{3}, \mathrm{ZnO}
$$

$\%$ weight loss of the second stage $=$

$$
=\frac{2 m_{\mathrm{Ag}_{2} \mathrm{CO}_{3}}+m_{\mathrm{ZnO}}}{m_{\mathrm{Ag}_{2} \mathrm{CO}_{3}}+m_{\mathrm{ZnCO}_{3}}} \approx 12 \%
$$

The third weight-loss stage in the TGA curve corresponds to the decomposition of silver carbonate to silver.

The cold-compressibility behavior of the synthesized powders was investigated using the Heckel, Panelli-Ambrosio and Ge models. Three plots were drawn: a plot was drawn with $\ln (1 / 1-D)$ along the $y$-axis and $\sqrt{P}$ along the $x$-axis (the Panelli-Ambrosio model - Figure 6); a plot was drawn with $\ln (1 / 1-D)$ along the $y$-axis and $P$ along the $x$-axis (the Heckel model - Figure 7); and a plot was drawn with $\lg (\ln (1 / 1-D))$ along the $y$-axis and $\lg P$ along the $x$-axis (the Ge model - Figure 8). Based on the $R^{2}$ values, it can be declared that the compaction data of the

\section{Panelli-Ambrosio Model}

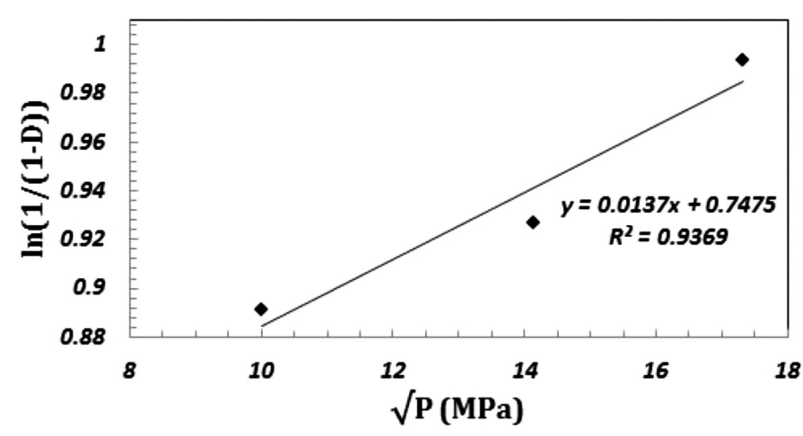

Figure 6: $\ln (1 / 1-D)$ versus the square root of uniaxial-pressure compaction magnitude $\sqrt{P}$ (the Panelli-Ambrosio equation)

Slika 6: Odvisnost $\ln (1 / 1-D)$ od kvadratnega korena nihanja tlaka pri enoosnem stiskanju $\sqrt{P}$ (enačba Panelli-Ambrosio) 


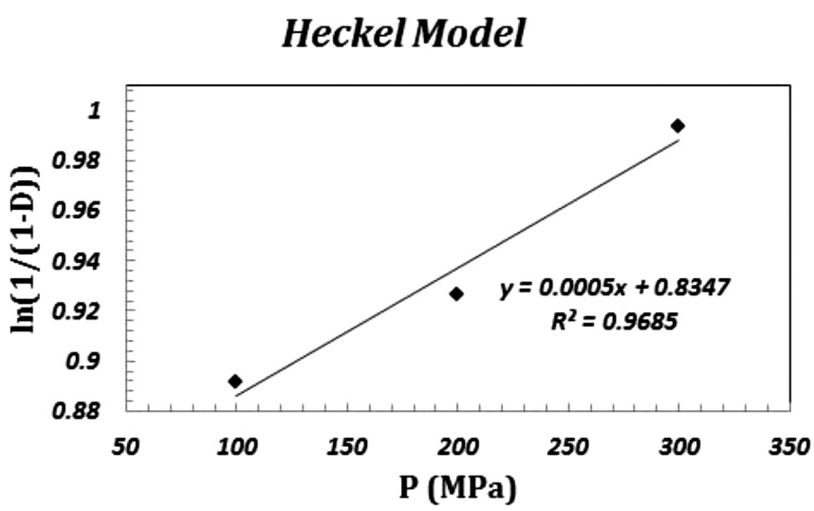

Figure 7: $\ln (1 / 1-D)$ versus uniaxial-pressure compaction magnitude $(P)$ (the Heckel equation)

Slika 7: Odvisnost $\ln (1 / 1-D)$ od nihanja enoosnega tlaka pri stiskanju $(P)$ (enačba Heckel)

synthesized powders was best fitted to the Heckel equation.

As mentioned before, the synthesized powders were sintered at $930{ }^{\circ} \mathrm{C}$, which is below the melting points of silver and zinc oxide. In other words, the powder compacts were sintered in the solid state. As it is known, during the solid-state sintering, the main mechanism for the densification and elimination of microstructural porosities is the diffusion of atoms. However, it can be declared that in the case of powder blends, the constituent with a relatively low melting point has a larger effect on the overall densification, which is due to the relatively low activation energy for the diffusion of atoms. So, in the case of the $\mathrm{Ag} / \mathrm{ZnO}$ powders, the dominant mechanism for the consolidation of the powder compacts is the diffusion of silver atoms during the sintering process. It is worthy to note that the melting points of zinc oxide and silver are $961.8^{\circ} \mathrm{C}$ and $1975{ }^{\circ} \mathrm{C}$, respectively.

Figure 9 shows the relative green and sintered densities versus the cold compaction prior to the sintering. On the basis of the obtained results, the samples that were cold compacted at $300 \mathrm{MPa}$ had the highest final

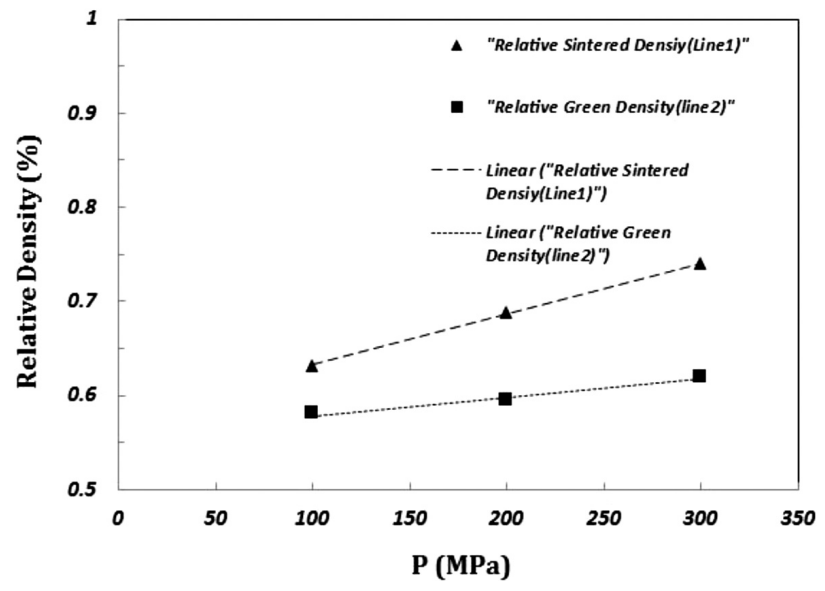

Figure 9: Green and sintered relative densities of the powders versus the magnitude of cold compaction prior to sintering

Slika 9: Zelene in sintrane gostote prahov v odvisnosti od hladnega stiskanja pred sintranjem

sintered relative density among the specimens. According to Figure 9, by increasing the cold-compaction pressure, the difference between the green- and final sintered-density values of the powder compacts was increased. However, the slope of line (1) is higher than that of line (2) in Figure 9. This observation implies that the cold-compaction pressure has a significant effect on the densification of the powder compacts during the solid-state sintering.

The difference between the relative sintered- and green-density values at each compression is shown in Figure 10. It seems that there is a logarithmic relationship between the difference value and the cold-compaction pressure. The value of correlation coefficient $R^{2}$ for the corresponding logarithmic curve is very close to unity. Based on the derived equation $(y=0.0622 \ln x-$ 0.2447 ), it can be concluded that if the cold-compaction pressure of the powders is below $38 \mathrm{MPa}$, no detectable densification will occur during the solid-state sintering $(y=0)$. More investigations should be done in this regard.

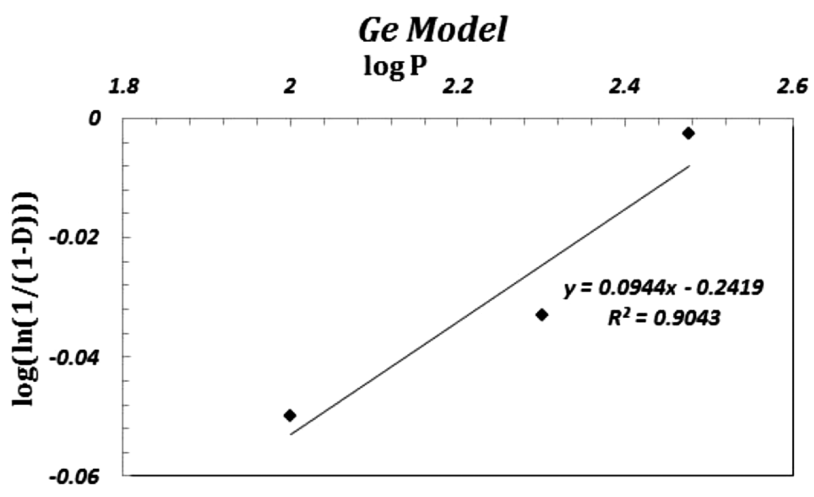

Figure 8: $\lg (\ln (1 / 1-D))$ versus uniaxial-pressure compaction magnitude $(\lg P)$ (the Ge equation)

Slika 8: Odvisnost $\lg (\ln (1 / 1-D))$ od nihanja enoosnega tlaka pri stiskanju $(\lg P)$ (enačba Ge)

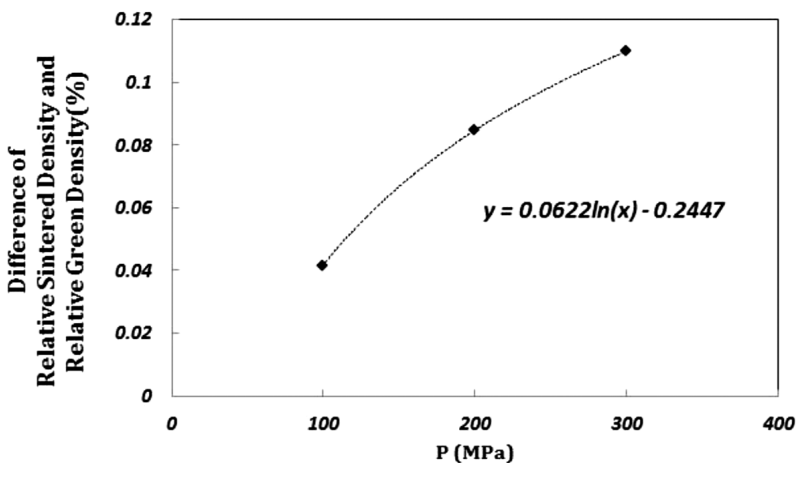

Figure 10: Difference between the relative sintered- and green-density values at each compression

Slika 10: Razlika vrednosti relativne sintrane in zelene gostote pri vsakem stiskanju 


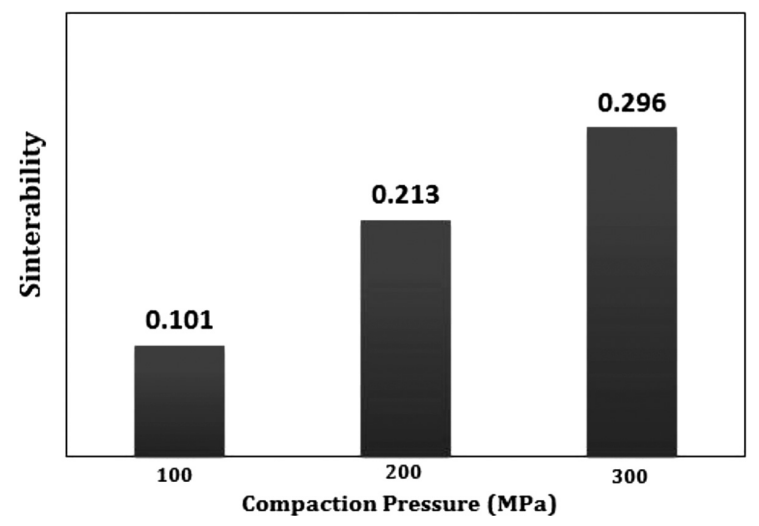

Figure 11: Sinterability $(\varphi)$ of the powder compacts at different cold-compaction pressures

Slika 11: Sposobnost sintranja $(\varphi)$ vzorcev, stisnjenih pri različnih tlakih v hladnem

The sinterability $(\varphi)$ of the synthesized powders is determined with the following Equation?

$$
\varphi=\left(d_{\mathrm{s}}-d_{\mathrm{g}}\right) /\left(d_{\mathrm{th}}-d_{\mathrm{g}}\right)
$$

where $d_{\mathrm{th}}, d_{\mathrm{g}}$ and $d_{\mathrm{s}}$ are the theoretical, green and sintered densities, respectively.

Figure 11 shows the sinterability of the powder compacts at different cold-compaction pressures. As it is observed, by increasing the cold-compaction pressure prior to sintering, the sinterability of the powder com-
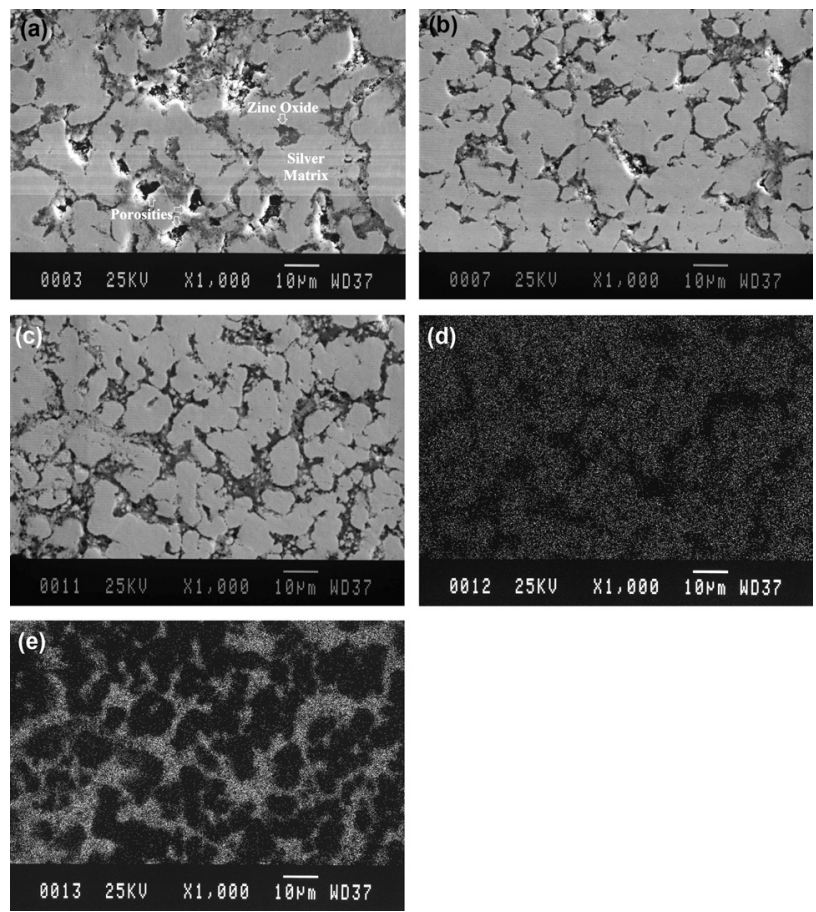

Figure 12: SEM images of the sintered composites cold compacted at: a) $100 \mathrm{MPa}$, b) $200 \mathrm{MPa}$ and c) $300 \mathrm{MPa}$ prior to sintering, d) silver map analysis of Figure 12c, e) zinc map analysis of Figure 12c

Slika 12: SEM-posnetki sintranih kompozitov, ki so bili hladno stisnjeni pri: a) $100 \mathrm{MPa}$, b) $200 \mathrm{MPa}$ in c) $300 \mathrm{MPa}$ pred sintranjem, d) analiza razporeditve srebra na Sliki 12c, e) analiza razporeditve cinka na Sliki 12c pacts was enhanced. So, it can be concluded that the magnitude of the cold-compaction pressure has a significant influence on the atomic diffusion during sintering. By increasing the cold-compaction pressure of the powder compacts, the plastic deformation of the powder particles led to an increase in the dislocation density within the microstructures of the particles.

Increasing the number of dislocations, which are one of the main diffusion paths for the diffusion of atoms, may facilitate atomic diffusion during the solid-state sintering. However, the annealing of the cold-worked powder particles during the solid-state sintering process leads to the annihilation of dislocations within the microstructures of the particles. So, it can be concluded that the positive effect of dislocations on the atomic diffusion is more important at the initial stage of the sintering process than at the intermediate or final stages.

SEM micrographs of the synthesized composites are shown in Figure 12. These figures also show an elemental-map analysis of the composites that were cold compacted at $300 \mathrm{MPa}$ prior to the sintering. The microstructures of the composites consist of the silver matrix, the zinc-oxide reinforcement and also porosities (Figures 12a to 12c). Figures $12 \mathbf{d}$ and $12 \mathrm{e}$ show the silver and zinc map analyses of Figure 12c. The white regions in Figures 12d and 12e are the silver and zinc oxide regions, respectively. It can be stated that the porosities mainly exist at the interface of silver and zinc oxide. However, by increasing the cold-compaction pressure, the size and volume fraction of the porosities were reduced. According to Figure 12, the samples that were cold compacted at $200 \mathrm{MPa}$ and $300 \mathrm{MPa}$ prior to the sintering contain silver regions within the bulk of the $\mathrm{ZnO}$ reinforcements. This fine dispersion of the constituents within the microstructures of the sintered specimens enhances the homogeneity of the synthesized composites.

\section{CONCLUSION}

In this study, $\mathrm{Ag} / \mathrm{ZnO}$ composites were synthesized via a chemical precipitation process. Silver and zinc carbonates were used as the precursors. The initial precipitates contained silver and zinc carbonates. The calcination of the precipitates at $600{ }^{\circ} \mathrm{C}$ occurred due to the decomposition of the carbonates and the formation of desired powder constituents, i.e., silver and zinc oxide. The compressibility-behavior investigations confirmed that the most accurate model for describing the compressibility behavior of the synthesized powders was the Heckel equation. Furthermore, the results showed that by increasing the cold-compaction pressure prior to sintering, the density of the synthesized composites was increased. 


\section{REFERENCES}

${ }^{1}$ ASM Handbook, Powder Metal Technologies and Applications, Vol. 7, ASM International, 1998

${ }^{2}$ E. Lassner, W. Schubert, Tungsten: Properties, Chemistry, Technology of the Element, Alloys and Chemical Compounds, Kluwer Academic Publishers, New York 1999, doi:10.1007/978-1-46154907-9

${ }^{3}$ W. G. Chen, Z. Y Kang, H. F. Shen, B. J. Ding, Arc Erosion Behavior of a Nanocomposite W-Cu Electrical Contact Material, Rare Metals, 25 (2006) 1, 37-42, doi:10.1016/S1001-0521(06)60011-9

${ }^{4}$ F. A Costa, A. G. P. Silva, F. A. Filho, U. U. Gomes, Solid state sintering of a W-25 wt\% Ag powder prepared by high energy milling, International Journal of Refractory Metals and Hard Materials, 26 (2008), 318-323, doi:10.1016/j.ijrmhm.2007.08.003

${ }^{5}$ E. R. Rangel, E. R. Garcia, J. M. Hernandez, E. T. Rojas, Alumina-based composites reinforced with silver particles, Advances in Materials, 2 (2013) 6, 62-65, doi:10.11648/j.am.20130206.11
${ }^{6}$ P. B. Joshi, V. J. Rao, B. R. Rehani, A. Pratap, Comparison of properties of silver-tin oxide electrical contact materials through different processing routes, Indian Journal of Engineering and Materials Science, 15 (2008), 236-240

${ }^{7}$ F. S. Jazi, N. Parvin, M. R. Rabiei, M. R. Tahriri, Z. M. Shabestari, A. R. Azadmehr, The effect of the synthesis route on the grain size and morphology of $\mathrm{ZnO} / \mathrm{Ag}$ nanocomposite, Journal of Ceramic Processing Research, 13 (2012) 5, 523-526

${ }^{8}$ M. Ardestani, Compaction and solid state sintering behavior of Cu-20wt. \% ZnO powders, Kovove Materialy - Metallic Materials, 51 (2013), 367-371, doi:10.4149/km_2013_6_367

${ }^{9}$ D. Jeyasimman, K. Sivaprasad, S. Sivasankaran, R. Narayanasamy, Fabrication and consolidation behavior of Al 6061 nanocomposite powders reinforced by multi-walled carbon nanotubes, Powder Technology, 258 (2014), 189-197, doi:10.1016/j.powtec.2014.03.039 